\title{
ACADEMIC PERFORMANCE AND ITS ASSOCIATION WITH CLASS ATTENDANCE, INTRINSIC MOTIVATION AND GENDER IN ENGINEERING STUDENTS
}

\author{
Waldyr Fong Silva ${ }^{1 *}$, Fredy Colpas Castillo ${ }^{2}$ and David Franco Borré ${ }^{3}$ \\ ${ }^{1,2,3}$ University of Cartagena. Cartagena de indias, Colombia \\ *Corresponding author: wfongs@ unicartagena.edu.co \\ Received September 2018; Accepted November 2018
}

\begin{abstract}
The association between academic performance, attendance to classes, intrinsic motivation and gender in 950 students of the engineering programs of the University of Cartagena between 2014 and 2016 was analyzed. The survey was used to evaluate the academic performance from the dimensions: conceptual, procedural and global. Class attendance and gender was assessed by teacher survey. The intrinsic motivation was evaluated through the CEVEAPEU questionnaire, which was designed and validated by Gargallo et. al (2009). For the relationship analysis, the variables were crossed and the bar diagrams and the $2 \times 2$ contingency tables were constructed applying the Chi-Square independence test. The values 0.89 (academic performance) and 0.90 (CEVEAPEU) for the Cronbach's Alpha, allowed to validate the instruments used. The results indicate that there is a significant degree of statistical significance $(\mathrm{p}<0.05)$ between academic performance and intrinsic motivation $(\mathrm{p}=0.0003)$ at a confidence level of $95 \%$. This means that the intrinsic motivation associated with enthusiasm, self-awareness, perseverance, mental agility and self-control have a relevant impact on the academic performance of the engineering student at the University of Cartagena. No statistical significance could be verified between the academic performance and the gender of the students. Nor between academic performance and class attendance of engineering students of the University of Cartagena at a 95\% level of confidence.
\end{abstract}

Keywords: Academic performance, Attendance to classes, intrinsic motivation, Gender.

\section{RENDIMIENTO ACADÉMICO Y SU ASOCIACIÓN CON LA ASISTENCIA A CLASES, MOTIVACIÓN INTRÍNSECA Y GÉNERO EN ESTUDIANTES DE INGENIERÍA}

Resúmen - Se analizó la asociación entre el rendimiento académico, asistencia a clases, motivación intrínseca y género en 950 estudiantes de los programas de ingeniería de la Universidad de Cartagena entre los años 2014 y 2016. La encuesta se utilizó para evaluar el rendimiento académico desde las dimensiones del rendimiento conceptual, procedimental y global. La asistencia a clases y género se evaluó por encuesta a docentes. La motivación intrínseca se evaluó mediante el cuestionario CEVEAPEU el cual fue diseñado y validado por Gargallo et. al (2009). Para el análisis de relación, se cruzaron las variables y se construyeron los diagramas de barra y las tablas de contingencia $2 \times 2$ aplicando la prueba de independencia Chi-Cuadrado. Los valores 0.89 (rendimiento académico) y 0.90 (CEVEAPEU) para el Alfa de Cronbach permitieron validar los instrumentos utilizados. Los resultados indican que existe un grado de significancia estadística importante $(\mathrm{p}<0.05)$ entre el rendimiento académico y la motivación intrínseca $(\mathrm{p}=0.0003)$ a un nivel de confianza del $95 \%$. Esto significa que la motivación intrínseca asociada al entusiasmo, autoconciencia, perseverancia, agilidad mental y autocontrol inciden de forma relevante en el rendimiento académico del estudiante de ingeniería de la Universidad de Cartagena. No se pudo comprobar significancia estadística entre el rendimiento académico y el género de los estudiantes asi como tampoco entre el rendimiento académico y la asistencia a clase de los estudiantes de ingeniería a un $95 \%$ de nivel de confianza.

Palabras Clave: Rendimiento académico, asistencia a clase, motivación intrínseca, escuela de procedencia. 


\section{Introduction}

For Castejón \& Pérez (1998), Pérez et al. (2008) it is important to identify the causal factors associated with academic performance and that may be associated with social, personal and institutional variables. That is, explanatory models that can provide information of a structural nature to describe the perception of students and teachers regarding the academic performance of university students are necessary. Goleman $(1995 ; 1996)$ associates academic performance with emotional intelligence where self-control is one of the components to reeducate in students and intrinsic motivation is decisive allowing the student to interact with the environment through the use of skills, self-awareness, enthusiasm, perseverance, empathy, mental agility and even feelings (Petrides et al.,2004; Lane et al.,2004; Navarro, 2003). Albalate et al. (2011) consider that the attendance to classes and the hourly intensity that students use in their academic process affect the results and academic goals where, in addition, the intrinsic motivation is directly associated with the previous knowledge that has (Soria \& Zuñiga, 2014). Also Nonis and Hudson (2006) consider that there is a relationship between attendance at classes, time spent by students in academic activities related to independent work developed outside the classroom and academic performance (De Zoysa \& Rudkin, 2007).

On the other hand, Lepper $(1988,1992,1996)$ considers that the motivated student intrinsically commits himself even more in processing information in a detailed and elaborated way making use of effective and deep learning strategies achieving greater commitment, dedication and significant mental effort in the development of tasks (Newby,1991). For Salonava et. al (2005), López et al. (2017), Fong et al.(2017) the intrinsic motivation is the engagement (psychological state associated with the studies which is positive and significant) which is characterized by the dedication, vigor and academic absorption of the student (Fong et al., 2016, 2017, 2018). For García \& San Segundo (2001), Barahona (2014), Van den Besselaar \& Sandström (2016), they were able to verify that the female sex was statistically associated in a positive way with academic performance. That is, for these authors the gender variable can be considered as a predictor of academic performance. For Rodríguez et al. (2004) and García (2000), this could be explained if we consider the fact that women dedicate more hours to study than men because they assume a greater commitment to their academic activities. Also for Garbanzo (2007) and Rodríguez et al. (2004), gender can not be considered directly related to academic performance.

In the present investigation the association between the academic performance of the university students with the attendance to classes, intrinsic motivation and gender was evaluated.

\section{Materials and Methods}

Population and sample size: The study participants were regular students of the fourth semester of the programs of Civil Engineering, Systems and Chemistry of the University of Cartagena. Of the total, 65\% were male and $35 \%$ female. The ages of the students were between 17 and 21 years old. To estimate the size of the sample when it comes to a finite population of less than 100,000 individuals is calculated according to Fong et al. (2017) and Stevenson (1981) by equation (1): 


$$
\mathrm{n}=\frac{\sigma^{2} \mathrm{Npq}}{\mathrm{e}^{2}(\mathrm{~N}-1)+\sigma^{2} \mathrm{pq}}
$$

$\mathrm{N}$ : Number of population elements; q: Probability that an element is not selected $(q=p) ; \sigma$ : Level of confidence or risk chosen; $n$ : Number of elements that the sample must have; $p$ : Probability that an element is selected (\% estimated); e: Error allowed.

Variables, phases, instruments and reliability of the test: The variables were classified into two (2) categories (independent and dependent):

a. Independent variables: Attendance to classes, intrinsic motivation and gender of the students.

b. Dependent variable: Academic performance

Intrinsic motivation was assessed using the SRLI (Self-Regulation of Learning Inventory) which is a questionnaire consisting of 80 weighted questions from 1 to 5 based on the Likert scale (Lindner et al.,1993).

The research was carried out in three (3) phases: In the first phase, the degree of academic achievement of engineering students was identified through a survey. In the second phase, the attendance to classes, intrinsic motivation and gender of the students participating in the study were evaluated. In phase 3 the independent variables are crossed with the dependent variable academic performance constructing the bar diagram of the relational analysis.

Instruments: The survey was used to assess academic performance from the dimensions of the conceptual performance (conceptualization), procedural (competence for solving problems) and global (groups the partial notes of conceptual and procedural performance) (Santos \& Vallelado,2013). Attendance to classes and gender was evaluated by teacher survey. The intrinsic motivation was evaluated through the CEVEAPEU questionnaire (questionnaire to evaluate the learning strategies in university students) which was designed and validated by Gargallo et al. (2009). To determine the reliability of the test the internal consistency was determined using the Cronbach Alpha (Cronbach,1951;Yurdugül,2008).

The dependent variable Academic Performance was classified into two categories: a) High academic performance (HAP) (HAP $\geq 75$ points out of 100 points) and Low academic performance LAP (LAP <75 points or less). The independent variables were classified into three categories: a) Attendance to classes: High class attendance (HCA) (score equal to or greater than 60 points; $\mathrm{HCA} \geq 60$ ) and Low class attendance (LCA) (score lower than 60; LCA < 60 points). b) Intrinsic motivation: high intrinsic motivation (HIM) (HIM $\geq 75$ points out of 100 points) and Low intrinsic motivation (LIM) (LIM <75 points or less). c) Gender: Female: F and Male: M.

Statistic analysis: The Chi-Square test (Fong et al., 2016) between academic performance and the independent variables class attendance, intrinsic motivation and gender was used to know which of these factors are related to each other in the engineering students of the University of Cartagena. 


\section{Results and Discussion}

According to equation 1, with a confidence level of 95\%, a sample size of 274 individuals is obtained. When applying the surveys, a total of 12 students per academic period and per program (4 programs, 6 academic periods) were made homogeneously for a total of 288 respondents. The Cronbach's Alpha (Cronbach,1951; Fong et al., 2018) for academic performance and intrinsic motivation (measured with the CEVEAPEU instrument) yielded the values 0.89 and 0.90 respectively, which indicates a high degree of internal consistency of each of the tests. The Chi-square test was evaluated for the analysis of the relationship between the dependent variable (academic performance) and the independent variables (attendance to classes, intrinsic motivation and gender).

Table 1 also indicates the values of $p$ (statistical significance), which also shows that there is a relationship of high statistical significance between academic performance and intrinsic motivation $(\mathrm{p}<0.05)$.

Table 1 Chi-Square Test for Academic performance

\begin{tabular}{|c|c|c|c|}
\hline Variable & Chi-square & GL & P-Value \\
\hline Class attendance & 0.06 & 1 & 0.8124 \\
\hline Intrinsic motivation & 13.37 & 1 & 0.0003 \\
\hline Gender & 2.68 & 1 & 0.1013 \\
\hline
\end{tabular}

** Relationship with high statistical significance at a confidence level of $95 \%$

Figure 1 shows the bar graph between academic performance and intrinsic motivation.

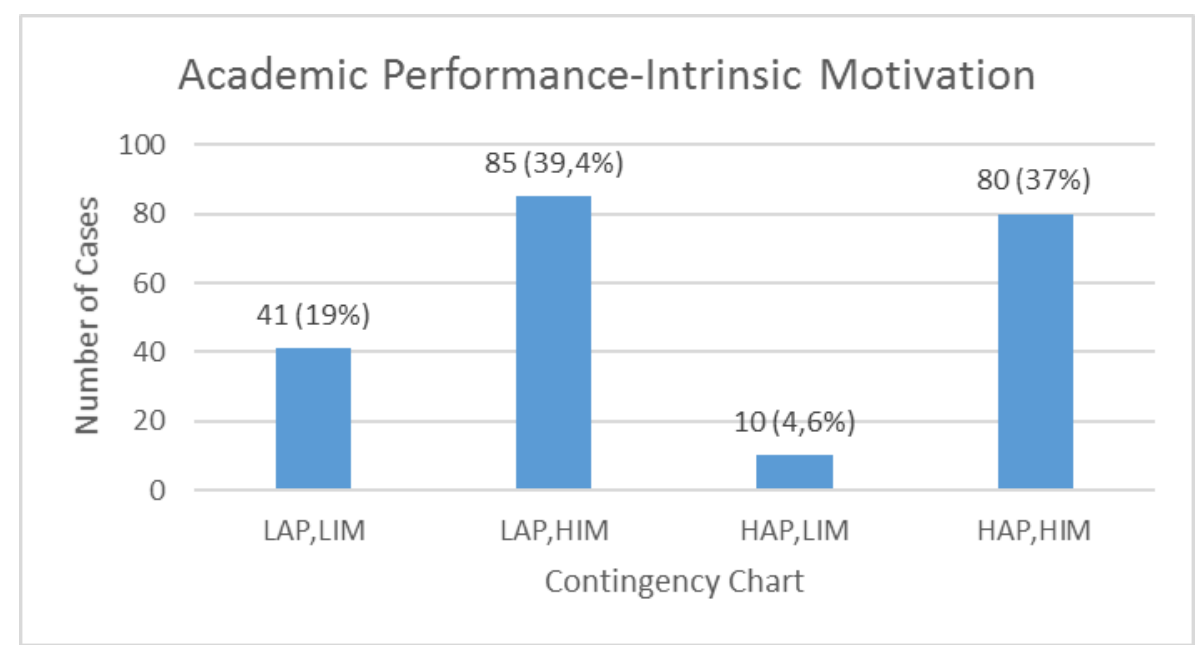

Figure 1. Bar graph: academic performance-intrinsic motivation.

$37 \%$ (80 cases) of students achieved high academic performance while developing high intrinsic motivation. This is because academic performance is associated with emotional intelligence which is significantly articulated with the student's intrinsic motivation as Goleman $(1995,1996)$ puts it. In the 
same way, it may be due to the intrinsically motivated student being a student committed to the efficient processing of the information he receives, implementing effective learning strategies that allow him to develop meaningful learning with greater commitment and dedication, fulfilling Lepper's postulates $(1988,1992,1996)$.

19\% (41 cases) of the students obtained low academic performance while developing low intrinsic motivation processes. This is due to the fact that a student who is not motivated has low engagement, as proposed by Salonava et. al (2005) and Fong et. al. (2018). 4.6\% (10 cases) of the students obtained a high academic performance despite having low intrinsic motivation processes. It is probable that this is due to the student's Engagement, that is to say, due to the very low intrinsic motivation that the student possesses, his psychological state associated with the studies can be positive and significant as posed by Salonava et. al (2005). The $39.4 \%$ (85 cases) of the students reached low academic performance despite having high intrinsic motivation processes. This may be due to unstable self-control processes where the student interacts with the academic environment without using the skills, enthusiasm, perseverance, mental agility or empathy sufficient to achieve their goals as stated by Goleman (1996) and Fong et al. (2016). In the same way it is likely that this group of students will require commitment, dedication and significant mental effort during the development of their tasks and academic activities as proposed by Lepper (1988).

In the present study it was not possible to verify the statistical significance between the academic performance with the attendance to classes and gender of the student.

\section{Conclusion}

There is statistical significance at a 95\% level of confidence between academic performance and intrinsic motivation in engineering students of the University of Cartagena. This is because intrinsic motivation is associated with factors that affect academic performance such as enthusiasm, self-awareness, perseverance, mental agility and self-control. There is no statistical significance at a 95\% level of confidence between the academic performance and the gender of engineering students at the University of Cartagena. No statistical significance could be verified at a 95\% confidence level between the academic performance and the class attendance of the engineering students.

\section{References}

Albalate, D., Fageda, X., and Perdiguero, J. (2011). Éxito académico, características personales y proceso de Bolonia: una aplicación econométrica. Revista d'Innovació Docent Universitària 3, 11-25.

Barahona U, Planck. Factores determinantes del rendimiento académico de los estudiantes de la Universidad de Atacama.(2014).Estudios pedagógicos, 40(1), 25-39.

Castejon, J. L., \& Perez, A. M. (1998). A causative explicative model of about the influence of psycho-social variables on academic achievement. Bordón, 50(2), 171-185.

Cronbach, L. J. (1951). Coefficient alpha and the internal structure of tests. psychometrika, 16(3), 297-334.

De Zoysa, A., \& Rudkin, K. (2007). Australian employment patterns and course participation preferences of accounting students. International Review of Business Research Papers, 3(1), 23-36.

IPSA SCIENTIA - Vol. 3 No $1-2018$ 
E.J. López-Pontón, W. Fong-Silva, D.A. Franco-Borre, C.A. Severiche-Sierra, J.D. Patino-Moncada (2017). Association between self-regulation of learning, motivation, teaching quality and sports dedication in engineering students. Contemporary Engineering Sciences, 10(18), 891-899.

Fong, W., Tarón, A. \& Colpas, F. (2016). Relación entre el inventario de autorregulación para el aprendizaje (SRLI) y algunos factores internos que inciden en el proceso enseñanza- aprendizaje de la química. IPSA SCIENTIA, 1(1), 58-68.

Garbanzo Vargas, Guiselle María (2007). Factores asociados al rendimiento académico en estudiantes universitarios, una reflexión desde la calidad de la educación superior pública. Revista Educación, 31(1),43-63.

García María Mercedes y San Segundo, María Jesús (2001). El rendimiento académico en el primer curso universitario. En: J. Gómez (Coord.). Actas X Jornadas de la Asociación de Economía de la Educación. Murcia. Pp. 435-445.

García, F. (2000). Factores escolares que determinan el rendimiento universitario. Revista española de pedagogía, 169(170), 497- 519.

Gargallo, Bernardo, Jesús M., Suárez-Rodríguez, \& Pérez-Pérez, Cruz (2009). El cuestionario CEVEAPEU. un instrumento para la evaluación de las estrategias de aprendizaje de los estudiantes universitarios. RELIEVE. Revista Electrónica de Investigación y Evaluación Educativa, 15(2),1-31.

Goleman,D.(1996). Emotional intelligence. Why it matters more than IQ. Learning, 24(6), pg 49-50.

Goleman,Daniel.(1995). Emotional Inteligence: Why it can matter more than IQ. New York: Bantam Books.

Lane, J., Lane, A. M., \& Kyprianou, A. (2004). Self-efficacy, self-esteem and their impact on academic performance. Social Behavior and Personality: an international journal, 32(3), 247-256.

Lepper, M. R. (1988). Motivational considerations in the study of instruction. Cognition and instruction, 5(4), 289-309.

Lepper, M. R., \& Cordova, D. I. (1992). A desire to be taught: Instructional consequences of intrinsic motivation. Motivation and emotion, 16(3), 187-208.

Lepper, M. R., Keavney, M., \& Drake, M. (1996). Intrinsic motivation and extrinsic rewards: A commentary on Cameron and Pierce's meta-analysis. Review of educational research, 66(1), 5-32.

Navarro, R. E. (2003). Factores asociados al rendimiento académico. Revista Iberoamericana De Educación, 33(1), 1-20.

Newby, T. J. (1991). Classroom motivation: Strategies of first-year teachers. Journal of educational psychology, 83(2), 195.

Nonis, S. and Hudson, G. (2006). "Academic performance of college students; influence of time spent studying and working" Journal of Education for Business, 81(3), 151-160.

Pérez, P. M., Costa, J. L. C., \& Vicente, M. P. C. (2008). Predicción del rendimiento académico desde las variables cognitivomotivacionales de un modelo de expectativa-valor. International Journal of Developmental and Educational Psychology, 4(1), 483-492.

Petrides, K. V., Frederickson, N., \& Furnham, A. (2004). The role of trait emotional intelligence in academic performance and deviant behavior at school. Personality and individual differences, 36(2), 277-293.

Rodríguez, S., Fita, E. \& Torrado, M. (2004). Rendimiento Académico en la Transición Secundaria-Universidad. Revista de Educación, 334(1), 391-414.

IPSA SCIENTIA - Vol. 3 No $1-2018$ 
Salanova Soria, M., Martínez Martínez, I.M., Bresó Esteve, E., Llorens Gumbau, S. y Grau Gumbau, R. (2005). Bienestar psicológico en estudiantes universitarios: facilitadores y obstaculizadores del desempeño académico. 21(1), 11-17.

Santos Álvarez, Ma Valle, \& Vallelado, Eleuterio (2013). Algunas dimensiones relacionadas con el rendimiento académico de estudiantes de Administración y Dirección de Empresas. Universitas Psychologica, 12(3),739-752.

Soria-Barreto, Karla, \& Zúñiga-Jara, Sergio (2014). Aspectos determinantes del éxito académico de estudiantes universitarios. Formación Universitaria, 7(5),41-50.

Stevenson, W.J. Statistics for Administration and Economy: Concepts and Applications, México: Harla, 1981.

Van den Besselaar, P., \& Sandström, U. (2016). Gender differences in research performance and its impact on careers: a longitudinal case study. Scientometrics, 106, 143-162. https://doi.org/10.1007/s11192-015-1775-3.

W. Fong-Silva, C.A. Severiche-Sierra J. Jaimes-Morales, Y.A. Marrugo-Ligardo and E.A. Espinosa-Fuentes. (2017). Cognition and Its Relationship with Endogenous and Exogenous Factors in Engineering Students. International Journal of Applied Engineering Research. 12(17), 6929-6933.

Waldyr Fong Silva, Remedios Pitre Redondo, Meredith Jimenez Cardenas (2018). Intrinsic motivation and its association with cognitive, actitudinal and previous knowledge processes in engineering students. Contemporary Engineering Sciences, 11(3), 129-138.

Waldyr Fong-Silva, Carlos Severiche-Sierra, Remedios Pitre-Redondo, Luz Vargas-Ortiz, Eduardo Espinosa-Fuentes (2017). Association between self-regulation of learning, student attitude, provenance and age in engineering students. Contemporary Engineering Sciences, 10(14), 665-672.

Waldyr Fong-Silva, Rebeca Curiel Gómez \& Clara Brito Carrillo. (2017). Aprendizaje significativo y su relación con la motivación intrínseca, escuela de procedencia y estrategias cognitivas en estudiantes de ingeniería. IPSA SCIENTIA, 2(1), 55-64.

Yurdugül, H. (2008). Minimum sample size for Cronbach's coefficient alpha: a Monte-Carlo study. Hacettepe Üniversitesi eğitim fakültesi dergisi, 35(35), 1-9.

IPSA SCIENTIA - Vol. 3 No $1-2018$ 